\title{
The Medicines Used for Control Diabetes in Brazil: Data from a National Survey
}

\author{
Micheline Marie Milward de Azevedo Meiners ${ }^{1 *}$, Noemia Urruth Leão Tavares ${ }^{1}$, Sotero Serrate Mengue ${ }^{2}$, Pedro \\ F Couto Vieira ${ }^{1}$, Andreia Turmina Fontanella ${ }^{2}$ and Edgar Merchán Hamann ${ }^{1}$
}

${ }^{1}$ Health Sciences Facultat- University of Brasília, Post Graduation Program on Public Health, Brazil

${ }^{2}$ University of Rio Grande do Sul, Post Graduation Program on Epidemiology, Brazil

Submission: February 23, 2018; Published: March 09, 2018

*Corresponding author: Micheline M M de A Meiners, Health Sciences Facultat- University of Brasília, Post Graduation Program on Public Health, Cond. Privê 1 Quadra 3, Conj. C, Casa 22, Brasília (DF), CEP 71539-315, Brazil, Tel: (55) 61-981755279; Email: michelinemeiners@gmail.com

Abstract

Aim: Describe the use of hypoglycemic agents, among people with diabetes in Brazil.

Methods: Data from the National Survey on Access, Use and Promotion of the Rational Use of Medicines in Brazil were used to establish the prevalence of medicines to control diabetes among participants. Results: The Biguanides (54.2\%) and the Sulfonylureas (29.1\%) were the most reported drugs used for the control of diabetes. The insulin and analogues was used by $13.9 \%$ of participants.

Conclusion: Brazil has a high rate of access to medicines to control diabetes. The rate of the use of Insulin needs improvement.

Keywords: Pharmacoepidemiology; Diabetes; Hypoglycemic agents; Health care access

\section{Background and Aims}

Since the early 2000s Brazil has been structuring programs for the healthcare of people with diabetes; With regard to medicines, in 2006 a federal law was passed to ensure, by the government, the access to medicines and supplies needed for the treatment of diabetes [1].Our objective is to describe the rate of the access and the hypoglycemic agents used among people with diabetes in Brazil.

\section{Methods}

During 2013-2014 the National Survey on Access, Use and Promotion of the Rational Use of Medicines in Brazil, with acronym PNAUM, was realized [2]. The survey is designed to be representative of the Brazil urban and noninstitutionalized population, on the basis of a complex, multistage probability sample. Survey participants are interviewed in their homes after signing the Informed Consent Term. The prevalence rates from the survey were weighted to ensure national and regional representation. Overall participants of the survey, we selected that which self-reported diabetes with 20 years old or more to realize this study. The prevalence of diabetes was $6.8 \%$ among participants. Data from medicines where self-reported and confirmed by showing the prescription or the packing of the drugs in use. The medicines for the control of diabetes are described by ATC Classification [3], on chemical subgroups - $4^{\text {th }}$ level. The research was approved by the National Ethical Committee.

\section{Results}

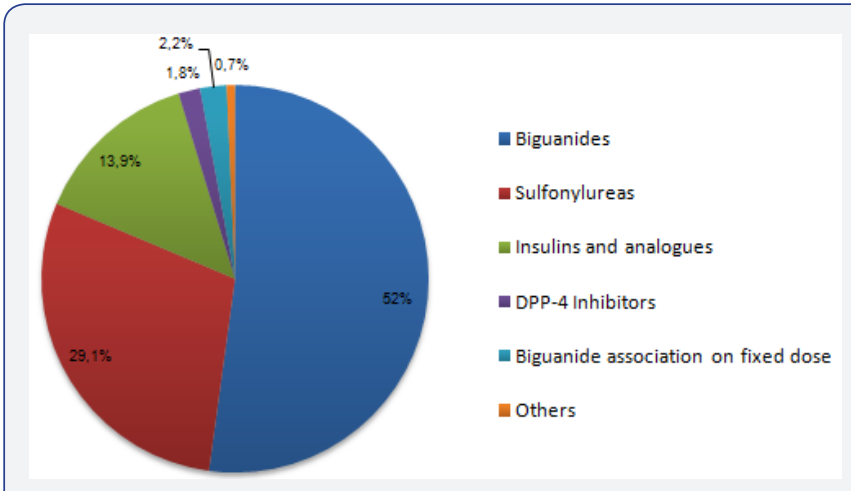

Figure 1: Frequency of antidiabetics use among self-reported people with diabetes $(\mathrm{N}=8,978,937)$. PNAUM, Brazil, 2013-14. 


\section{Current Research in Diabetes \& Obesity Journal}

Most participants (85.8\%) had indication for treatment with Blood glucose lowering medicines (excluded insulin), among these, $92.7 \%$ reported the use of one or more medicines. $18,1 \%$ reported the prescription of insulin, however, only $87,9 \%$ these were in regular use. Considering all medicines used for treatment with Blood glucose lowering medicines, the Biguanides was the most reported, alone (52\%) or in fixed dose associations $(2.2 \%)$, then, the Sulfonylureas $(29,1 \%)$. The insulin and analogues was used by $13,9 \%$ of participants. The utilization of new medicines was low among the participants shown in Figure 1.

\section{Conclusion}

The Brazilian governmentfinances metformin, glibenclamide, glicazide and insulin (regular and NPH). We observed a high rate of diabetes treatment among participants, what indicates a good access to medicines. However, insulin prescription was lower than recommended by clinical protocols, for example $25 \%$ by American Diabetes Association [4], probably related to the fears and myths associated to its use.

\section{Acknowledgement}

PNAUM was funded by Ministry of Health. Our gratitude for PNAUM team that contributed for data recollection and database.

\section{References}

1. Brazil Federal Law 11.347 (2006) Act for the free distribution of drugs and necessary materials for its application and capillary glycaemia monitoring for persons with diabetes mellitus enrolled in diabetic education programs. Diário Oficial da União, Brasília, DF, 28 de set. Seção 1, p.1.

2. Mengue SS, Bertoldi AD, Boing AC, Tavares NU, Pizzol TD, et al. (2016) National Survey on Access, Use and Promotion of Rational Use of Medicines (PNAUM): household survey component methods. Rev Saúde Pública 50(Suppl 2): 4s.

3. WHO Collaborating Centre for Drug Statistics Methodology (2017) The Anatomical Therapeutic Chemical (ATC) classification system index with DDDs. Oslo, Norway.

4. Shubrook J, Butts A, Chamberlain JJ, Johnson EL, Leal S, et al. (2017) Standards of medical care in diabetes-2017 abridged for primary care providers. Clinical Diabetes 35(1): 5-26.

Your next submission with Juniper Publishers will reach you the below assets

- Quality Editorial service

- Swift Peer Review

- Reprints availability

- E-prints Service

- Manuscript Podcast for convenient understanding

- Global attainment for your research

- Manuscript accessibility in different formats

( Pdf, E-pub, Full Text, Audio)

- Unceasing customer service

Track the below URL for one-step submission https://juniperpublishers.com/online-submission.php 